\title{
PENGGUNAAN MAKIAN BAHASA INDONESIA PADA KOLOM KOMENTAR AKUN INSTAGRAM LAMBE TURAH (KAJIAN SOSIOLINGUISTIK)
}

\author{
Dewi Yanti ${ }^{1}$, Rai Bagus Triadi $^{2}$ \\ Dosen Program Studi sastra Indonesia, Universitas Pamulang \\ dosen01160@unpam.ac.id ${ }^{1,}$ molikejora12@gmail.com²
}

\begin{abstract}
Abstrak
Penelitian ini dilakukan atas dasar ketertarikan peneliti pada maraknya penggunaan bahasa makian dalam media Instagram khususnya pada akun gossip Lambe Turah sebagai salah satu akun gossip ternama yang banyak mengundang komentar negatif para warganet/ heters terkait berbagai unggahan informasi para selebriti atau kejadian-kejadian yang tengah viral di masyarakat. Pesatnya perkembangan jaman dan teknologi di Indonesia berdampak pada penggunaan makian yang dilakukan dalam aktivitas berbahasa masyarakat Indonesia. Penggunaan bahasa lisan kini tidak hanya dalam ragam lisan, kini menyebar pula pada ragam tulis. Metode penelitian yang digunakan yaitu metode penelitian deskriptif kualitatif dengan menggunakan data dalam tangkapan layar dan dibentuk dalam kolom data makian. Berdasarkan proses analisis data, bahwa indeks usia, jenis kelamin dan pendidikan memengaruhi pada referensi makian yang dihasilkan.
\end{abstract}

Kata kunci: Makian, akun instagram, Lambe Turah, sosiolinguistik

\section{Pendahuluan}

Bahasa digunakan untuk berkomunikasi dengan satu sama lain. Bahasa itu sendiri membuat hubungan manusia menjadi semakin dekat hari demi hari (Brown, 1987). Bahasa merupakan media komunikasi dan interaksi antar anggota masyarakat .Ketika dua atau lebih orang berkomunikasi satu sama lain, kita dapat mengatakan sistem komunikasi yang mereka gunakan sebagai kode. Dari sebagian besar kasus 
yang terjadi di dalam komunikasi, kode tersebut disebut sebagai sebuah bahasa (Wardhaugh 2006).

Dalam kehidupan bersosial, terkadang kita menggunakan bahasa yang munkin dapat menyinggung orang yang daiajak berbicara. Ungkapan tersebut sering disebut atau dikategorikan makian. Seiring pesatnya perkembangan teknologi, penggunaan makian tempaknya semakin mewarnai aktivitas berbahasa manusia, penggunaan makian tersebut baik berupa bahasa lisan maupun tulisan. Berbagai media sosial yang menjamur, menjadi salah satu wadah interaksi sosial tidak langsung yang sering memunculkan berbagai makian atas situasi yang terjadi. Berbagai akun gossip pada media Instagram merupakan salah satu media komunikasi yang banyak memancing emosi hingga memunculkan berbagai respon negatif hingga makian dari warganet.Dalam penelitian ini, peneliti memfokuskan penelitian pada lebih khusus lagi, peneliti dalam penelitian ini akan meneliti penggunaan makian bahasa Indonesia pada kolom komentar akun Instagram Lambe Turah berdasarkan variabel sosiolinguistik.

\section{Metode Penelitian}

Metode penelitian yang digunakan dalam penelitian ini adalah metode kualitatif. Penelitian berusaha mengamati setiap komentar warga net/ heters yang mengandung makian pada kolom komentar akun Instagram lambe turah pada unggahan Maret, Apri dan Mei. Adapun data yang telah dikelompokkan tersebut akan diklasifikasi berdasarkan subfokus penelitian sebagai berikut: data berdasarkan bentuk lingual, variasi referensi dan kelas sosial. Dalam memilih data, peneliti menggunakan metode purposive sampling. Purposive sampling adalah pengambilan sampel yang digunakan peneliti untuk memilih individu dan tempat untuk belajar atau mengerti tentang fenomena utama. Dalam penelitian ini teknik pengumpulan data yang peneliti gunakan berupa tangkapan layar/screen shoot unggahan pada kolom komentar akun Instagram Lambe Turah. Selanjutnya selektif mencari bentuk makian, peneliti 
mengelompokkan data dengan seksama sesuai dengan fokus penelitian yaitu ragam bentuk, variasi referensi dan pengaruh perbedaan kelas sosial kepada pemakaian makian. Setelah itu, peneliti mengelompokkan data berdasarkan fokus penelitian dengan memberikan kode pada kartu data kemudian melakukan penganalisisan.

\section{Pembahasan}

Setelah peneliti melakukan pengumpualan data dari media sosial Instagram, yaitu akun gossip Lambe Turah. Berikut beberapa tangkapan layar/ Screen shoot bentuk makian yang dilakukan warganet/ heters terkait berbagai berita/ peristiwa yang diunggah di laman tersebut

\begin{tabular}{|c|c|c|}
\hline $\begin{array}{l}\text { No Urut } \\
\text { Data }\end{array}$ & Bentuk Makian & $\begin{array}{l}\text { Waktu } \\
\text { Unggah }\end{array}$ \\
\hline Data 1 & Istrinya yang dodol padahal & 28 April \\
\hline Data 2 & $\begin{array}{l}\text { tolol aja tuh orang nendang anak kecil, pikirannya di } \\
\text { mana? }\end{array}$ & \\
\hline Data 3 & Bapak goblok main tending & \\
\hline Data 4 & bapak tolol & \\
\hline Data 5 & $\begin{array}{l}\text { ni sih bapaknya yang bodoh, orang lagi main ayunan, lah } \\
\text { anaknya dia gk dijaga pake nendang segala }\end{array}$ & \\
\hline Data 6 & $\begin{array}{l}\text { Setan bener tuh bapak, melarat bener, mata sipit tuh yang } \\
\text { buat ulah lagi. }\end{array}$ & \\
\hline Data 7 & Ah tai & 17 Maret \\
\hline Data 8 & Acara alay & \\
\hline Data 9 & Gimic semata & \\
\hline Data 10 & Awas gigi nyangkut & \\
\hline Data 11 & Muka lu yang kaya ee & \\
\hline
\end{tabular}




\begin{tabular}{|c|c|c|}
\hline Data 12 & Biji pe*ler kali & \multirow[t]{7}{*}{29 Maret } \\
\hline Data 13 & Aku waria yang sedang jatuh cinta & \\
\hline Data 14 & Banci plastic & \\
\hline Data 15 & Sekong tetap aja sekong & \\
\hline Data 16 & Cakep banget nih banci... & \\
\hline Data 17 & Jisss kotor & \\
\hline Data 18 & Wong gendeng & \\
\hline
\end{tabular}

Berdasarkan pemaparan beberapa data di atas, maka hasil pembahsannya adalah sebagai berikut:

Makian bahasa Indonesia berbentuk kata dasar

Adapun data tersebut sebagai berikut.

Data01. Istrinya yang dodol padahal

Data02 tolol aja tuh orang nendang anak kecil, pikirannya di mana?

Data 03 Bapak goblok main tendang

Data 05 ni sih bapaknya yang bodoh, orang lagi main ayunan, lah anaknya dia gk dijaga pake nendang segala

Data 06 Setan bener tuh bapak, melarat bener, mata sipit tuh yang buat ulah lagi.

Data 07 ah Tai

Data 08 acara alay

Apabila dianalisis dengan mengunakan pendekatan sintaksis dapat disimpulkan pada umumnya makian yang berbentuk kata dasar kehadirannya berada di belakang klausa inti seperti pada data 03 dan 05. Pada data 06 ada penggunaan makian setan menjelaskan kelas kata nomina. 


\section{Makian Berbentuk Kata Turunan}

Bentuk lingual makian bahasa Indonesia pada media sosial yang berbentuk kata turunan merupakan ungkapan makian yang dibentuk lebih dari saru morfem, atau dapat dikatakan makian yang sudah mengalami proses morfologi.

Data 08: acara alay

Data 09: gimic semata

Data 11: muka lu kaya ee

Berdasarkan bentuk-bentuk makian di atas, dapat diketahui bahwa makian kata turunan bahasa Indonesia pada media sosial terdapat dua jenis, yaitu kata turunan yang distribusi letaknya terdapat di luar klausa inti dan kata turunan yang distribusinya terdapat pada klausa inti. makian bentuk turunan teletak setelah dan sebelum klausa inti.

Pada klauasa "acara alay" bentuk "alay" terletak Kata turunan ini menjelaskan makian yang mengarah pada sesuatu yang terkesan tidak bermutu atau murahan. Selanjutnya, Pada kalimat "muka lu kaya ee” kalimat ini memberikan pengibaratan muka seperti tai, yang bentuk turunan dalam kalimat tersebut adalah "ee", selanjutnya pada frasa "gimic semata" merupakan turunan dari Bahasa sing yang mengartikan sebuah kebohongan atau kepura-puraan.

Terakhir, proses analisis ditujukan pada makian yang mengalami proses pemajemukan. Pada data tersebut yang termasuk kedalam bentuk kata turunan pemajemukan adalah data14, 17 dan 18. Makian banci plastik, jiss kotor dan wong gendeng adalah contoh makian kata majemuk yang terdapat pada media sosial.

\section{Makian bahasa Indonesia berbentuk frasa}

Terdapat bentuk lingual frasa letak makian tersebut tidak jauh berbeda dengan kata. Letak makian ini ada yang berada di dalam klausa inti dan di luar klausa inti. Frasa yang terdapat pada klausa inti biasanya menduduki fungsi sintaksis subjek dan predikat, untuk fungsi subjek, makian mengantikan orang yang dimaki, sedangkan 
untuk fungsi predikat biasanya memberikan keterangan untuk memaki orang, situasi, atau keadaan yang dituju oleh penulis status. Adapun data-data yang menunjukan makian berbentuk frasa sebagai berikut.

Data 04 Bapak tolol

Data 14 Banci plastik

\section{Makian bahasa Indonesia berbentuk klausa}

Penggunaan makian bahasa Indonesia berbentuk klausa pada kolom komentar akun instagram Lambe Turah terdapat pada data di bawah ini.

Data 04 Bapak goblok main tending

Data 05 ini sih bapaknya yang bodoh...

Data 13 aku waria yang sedang jatuh cinta

Data 16 cakep banget nih banci

Berdasarkan data di atas dapat diketahui bahwa makian yang berbentuk klausa terdapat kata atau frasa yang diikuti oleh pronomina. Kehadiran pronomina pada data tersebut terletak di belakang kata atau frasa makian. Contoh terdapat pronomina " $a k u$ " pada makian "aku waria” Pronomina ini bergabung pada bentukan makian " cakep banget ni banci” dan "ini sih bapaknya yang bodoh”.

\section{Variasi Referensi Makian Bahasa Indonesia Kolom Komentar Lambe Turah}

Makian bahasa Indonesia pada media kolom komentar lambe turah memiliki refensi keadaan yang beragam. Keberagaman ini terlihat ketika penulis media sosial berupaya menggambarkan berbagai macam situasi atau keadaan yang ada, misal: jiss kotor. Referensi makian yang ketiga adalah keadaan fisik seseorang yang kurang baik seperti pada "mata sipit tuh yang buat ulah lagi". Terakhir, makian yang memiliki referensi pada keadaan yang melanggar agama atau aturan tuhan, misal pada data banci plastik. Referensi benda diantaranya:biji p*ler, tai dan e'e. Referensi Mahluk 
Halus pada data yaitu pada Setan bener tuh bapak, melarat bener, mata sipit tuh yang buat ulah lagi.

\section{Pemakaian Makian Berdasarkan Indeks Penutur}

\section{Indeks Usia}

Indeks usia berkaitan pada usia berapa pemilik akun tersebut menuturkan makian dengan jenis-jenis tertentu. Pada penelitian ini peneliti mencoba mengkategorikan usia berdasarkan tiga jenis kategori yaitu usia remaja, usia dewasa, dan usia tua. Kategori tersebut dilakukan untuk mempermudah menghitung rentang usia pemilik akun media sosial.

Berdasarkan data yang diperoleh 18 data dari 18 pemilik akun Instagram yang berkomentar pada kolom komentar lambe turah sebesar $60 \%$ pemilik akun tersebut berada pada usia dewasa, sedangkan $40 \%$ berada pada kategori remaja. Berdasarkan hal tersebut dapat diambil kesimpulan sementara bahwa pemilik akun yang paling sering mengeluarkan kata-kata dalam bentuk makian adalah rentang usia dewasa.

\section{Indeks Jenis Kelamin}

Indeks jenis kelamin sangat berpengaruh terhadap pemilihan diksi makian pada media sosial. Berdasarkan berbagai penelitian perspektif gender yang ada, banyak peneliti menyimpulkan terdapat perbedaan penggunaan bahasa bila dikaitkan dengan gender.

Berdasarkan analisis data yang telah dilakukan, terdapat simpulan bahwa jenis kelamin perempuan identik menggunakan makian yang lebih halus daripada laki-laki. Hal ini berpatokan kepada data yang didapat oleh peneliti, tidak ditemukan makian yang dibuat oleh jenis kelamin perempuan yang menggunakan referensi binatang. Hal ini perlu dikritisi karena menurut peneliti makian-makian jenis tersebut dikategorikan makian yang paling kasar atau secara psikologis paling menyakitkan bagi pembaca. 
Selanjutnya mengenai sasaran makian, pengguna akun media sosial berjenis kelamin perempuan banyak menggunakan makian untuk mengungkapkan kekesalan kepada lawan jenis atau keadan yang tidak menyenangkan pada dirinya, hal tersebut dapat terlihat pada data berikut.

\section{Indeks Tingkat Pendidikan}

Terdapat perbedaan penggunaan makian, baik itu bentuk lingualnya ataupun referensinya apabila dikaitkan dengan tingkat pendidikan yang dimiliki oleh masingmasing pemilik akun instagram. Tingkat pendidikan adalah sebagai salah satu alat pembeda dimana seseorang menempati kelas sosialnya. Dalam proses penggalian data, tingkat pendidikan pemilik akun peneliti mengalami kesulitan. Kesulitan tersebut dikarenakan banyak pemilik akun yang tidak menampilkan tingkat pendidikan di informasi profil mereka.

\section{Simpulan}

Berdasarkan hasil analisis data yang dilakukan peneliti pada bagian sebelumnya, maka dapat ditarik simpulan dalam penelitian ini bahwa ragam bentuk lingual makian bahasa Indonesia pada kolom komentar akun Instagram Lambe Turah terdiri dari beberapa bentuk ragam lingual, antara lain bentuk lingual kata, frasa, klausa dan kalimat. Referensi bentuk lingual dalam bahasa Indonesia sangat beragam. Hal ini menjadi sebuah keunikan tersendiri, karena perbedaan latar budaya, pendidikan, jenis kelamin sangat berpengaruh terhadap penggunaan referensi makian sebuah bahasa.

Persentasi $80 \%$ wanitalah yang ikut berkomentar dalam kolom, sehingga komentar yang muncul tidak ada yang mengarah pada referensi binatang.hal ini terkait dengan indek jenis kelamin. Persentasi terbesar makian dilakukan oleh orang dewas, kemudian remaja. Memaki dalam media sosial dapat berbahaya ketika sasaran makian tersebut menjadi dua arah, berbeda dengan tuturan langsung yang kita 
lakukan dalam proses komunikasi. Hal ini dapat berakibat terjadinya salah persepsi antara pengguna media sosial (khususnya istagram/ akun lambe turah) tersebut.

\section{DAFTAR PUSTAKA}

Ballen J. P. and S.Pit Corder (ed). 1975. Papers in Applied Linguistics. Oxford:

Oxford University Press.

Brown, H. Douglas. 1987. Principles of Language Learning and Teaching. Englewood Cliffs, NJ: Prentice Hall.

Creswell, Jhon. 2015. Riset Pendidikan. Yogyakarta: Pustaka Belajar.

Chaer, Abdul. 2009. Sosiolinguistik: Perkenalan Awal. Jakarta : Rineka Cipta.

Fishman, Joshua. 1972. A Sosiolinguistics: a brief introduction. Rowley Massachusetts: Newbury House Publisher.

Hickerson ,Nancy Parrot. 1980. Linguistik Anthropology. New York: Holt, Rinehart and Winston Inc.

Holmes, Janet. 2001. An introduction to Sociolinguistics (Second edition). London; Longman.

Hymes, Dell. 1972. Models of Interactions of Language and Social Life. Eds Direction in Sociolinguistics. New York: Rinehart And Winston Inc.

Langacker, W. 1973. New York: Harcourt Brace Jovanovich, Inc.

Mahsun. 2007. Metode Penelitian Bahasa: Tahapan Strategi, Metode, dan Tekniknya. Jakarta: Raja Grafindo Persada.

Soerjono, Soekanto. 2002. Sosiologi Suatu Pengantar. Jakarta: Raja Grafindo Persada. 